\title{
Bone metabolism and mineralisation after cytotoxic chemotherapy including ifosfamide
}

\author{
J de Schepper, S Hachimi-Idrissi, O Louis, R Maurus, J Otten
}

\begin{abstract}
Lumbar spine bone mineral density and bone mineral metabolism were studied in 13 children three months or more after completion of cytotoxic chemotherapy that included ifosfamide given for different malignancies. Blood and urine were analysed for calcium, phosphorus, and magnesium and blood for alkaline phosphatase activity, parathyroid hormone, and $1,25(\mathrm{OH})_{2}$ vitamin $D_{3}$. Bone mineral density (BMD) was measured at the lumbar spine (L1-L4) using a commercial dual $x$ ray absorptiometer. Serum concentrations of calcium, phosphorus, and magnesium and alkaline phosphatase activity, as well as plasma $1,25(\mathrm{OH})_{2}$ vitamin $D_{3}$ concentrations were normal in all children. Slightly raised parathyroid hormone concentrations were seen in two children. An increased urinary excretion of calcium was found in five children. Mean (SD) BMD of the children was -0.88 $(1 \cdot 44)$. Three children had osteopenia, as defined by a BMD lower than -2 SD for age and sex related standards. No significant relation was found between the BMD and the biochemical parameters. In conclusion, a normal BMD was found in most patients who had received ifosfamide, even in those with persisting hypercalciuria. (Arch Dis Child 1994; 71: 346-348)
\end{abstract}

Ifosfamide is increasingly being used to treat solid tumours in children and has become frontline treatment of soft tissue sarcomas. ${ }^{1}$ Its side effects include transient and permanent tubular damage, leading to metabolic acidosis, renal phosphate loss, and hypercalciuria, which in turn lead to a defective bone mineralisation in growing children. ${ }^{2} 10$ Therefore, we screened children who received chemotherapy including ifosfamide for an insufficient bone mineralisation and abnormalities in the bone mineral metabolism.

\section{Patients and methods}

Thirteen patients or their parents gave their informed consent for the study. The characteristics of the patients and the treatment received are shown in table 1 . The age of the patients ranged between 2.9 and $17 \cdot 4$ years at the time of the study, which was performed between three and 147 months after completion of chemotherapy.

All patients, who had received various cytotoxic treatments (but all including ifosfamide) given for different malignancies (in most cases a rhabdomyosarcoma), were off any medical treatment at the time of the study. One patient had presented a malignant hypercalcaemia at the start of the treatment (patient 7), whereas another child had been treated for ifosfamide related hypophosphataemic rickets one year previously for three months (patient 1 ). Two patients (patients 5 and 9) had received respectively cerebral and axillary irradiation as part of their treatment. Bone mineral density (BMD) was measured at the level of the lumbar spine (L1-L4) by dual $x$ ray absorptiometry with a commercial densitometer (Hologic QDR $1000 / \mathrm{W}$, Waltham, USA). Lumbar spine

Akademisch
Ziekenhuis, Vrije
Universiteit Brussel,
Brussels, Belgium,
Department of
Paediatrics
J de Schepper
S Hachimi-Idrissi
R Maurus
J Otten
Department of
Radiology
O Louis
Correspondence to:
Dr J de Schepper, Division of
Paediatric Endocrinology,
Department of Paediatrics,
University Hospital VUB,
Laarbeeklaan 101, B-1090
Brussels, Belgium.
Accepted 25 May 1994

Table 1 Characteristics of patients studied and treatment received

\begin{tabular}{|c|c|c|c|c|c|c|c|}
\hline $\begin{array}{l}\text { Patient } \\
\text { No }\end{array}$ & $\operatorname{Sex}$ & $\begin{array}{l}\text { Age } \\
\text { (years) }\end{array}$ & Disease status & Irradiation & $\begin{array}{l}\text { Time lapse from } \\
\text { last ifosfamide } \\
\text { (months) }\end{array}$ & $\begin{array}{l}\text { Total dose } \\
\text { of ifosfamide } \\
\left(\mathrm{g} / \mathrm{m}^{2}\right)\end{array}$ & Other cytotoxic agents ${ }^{\star}$ \\
\hline 1 & $\mathrm{~F}$ & $3 \cdot 7$ & Embryosarcoma & No & 18 & 60 & - \\
\hline 2 & $\mathbf{M}$ & $2 \cdot 9$ & Rhabdomyosarcoma & No & 6 & 60 & - \\
\hline 3 & $\mathbf{F}$ & $3 \cdot 3$ & Rhabdomyosarcoma & No & 4 & 60 & - . . . . . . . . \\
\hline 4 & $\mathrm{~F}$ & $6 \cdot 1$ & Rhabdomyosarcoma & No & 15 & $12 \cdot 5$ & $\begin{array}{l}\text { Carboplatin, epirubicin, VP-16, } \\
\text { cyclophosphamide, doxorubicin } \\
\text { hydrochloride }\end{array}$ \\
\hline 5 & $\mathbf{F}$ & $6 \cdot 4$ & Rhabdomyosarcoma & Yes & 51 & 12 & $\begin{array}{l}\text { Doxorubicin hydrochloride, } \\
\text { cyclophosphamide, cisplatin }\end{array}$ \\
\hline 6 & $\mathbf{M}$ & $10 \cdot 3$ & Rhabdomyosarcoma & No & 39 & 60 & \\
\hline 7 & $\mathbf{M}$ & $8 \cdot 3$ & B cell leukaemia & Yes & 12 & $12 \cdot 7$ & $\begin{array}{l}\text { Doxorubicin hydrochloride, } \\
\text { cyclophosphamide, methotrex- } \\
\text { ate, prednisolone, VP-16 }\end{array}$ \\
\hline 8 & $\mathbf{M}$ & $9 \cdot 5$ & B cell leukaemia & No & 5 & $12 \cdot 0$ & $\begin{array}{l}\text { Doxorubicin hydrochloride, } \\
\text { cyclophosphamide, methotrex- } \\
\text { ate, prednisolone, VP-16 }\end{array}$ \\
\hline 9 & M & $9 \cdot 5$ & Rhabdomyosarcoma & No & 17 & 60 & Carboplatin, epirubicin, VP-16 \\
\hline 10 & $\mathbf{M}$ & $17 \cdot 4$ & Rhabdomyosarcoma & No & 29 & 24 & $\begin{array}{l}\text { Vindesine, cisplatin, doxorubicin } \\
\text { hydrochloride, methotrexate }\end{array}$ \\
\hline 11 & M & $13 \cdot 8$ & Synovialis sarcoma & No & 147 & 36 & \\
\hline 12 & $\mathbf{M}$ & $14 \cdot 4$ & Osteosarcoma & No & 12 & 12 & $\begin{array}{l}\text { Carboplatin, epirubicin, VP-16, } \\
\text { cyclophosphamide, doxorubicin } \\
\text { hydrochloride }\end{array}$ \\
\hline 13 & $\mathbf{F}$ & $13 \cdot 3$ & Rhabdomyosarcoma & No & 3 & 60 & - \\
\hline
\end{tabular}

*All patients also received vincristine and actinomycin D. Doxorubicin hydrochloride given as Adriamycin. VP-16=etoposide. 
Table 2 Results of determinations showing calcium and phosphorus metabolism and BMD measurements

\begin{tabular}{|c|c|c|c|c|c|c|c|c|c|}
\hline \multirow[b]{2}{*}{$\begin{array}{l}\text { Patient } \\
\text { No }\end{array}$} & \multicolumn{5}{|l|}{ Serum } & \multicolumn{4}{|l|}{ Urine } \\
\hline & $\begin{array}{l}\text { Calcium } \\
\text { (mmoll) }\end{array}$ & $\begin{array}{l}\text { Phosphorus } \\
\text { (mmoll) }\end{array}$ & $\begin{array}{l}\text { Alkaline } \\
\text { phosphatase } \\
\text { (U/) }\end{array}$ & $\begin{array}{l}\text { Parathyroid } \\
\text { hormone } \\
(\text { ng/l) }\end{array}$ & $\begin{array}{l}1,25(\mathrm{OH})_{2} \\
\text { vitamin } \mathrm{D}_{3}\end{array}$ & $\begin{array}{l}\text { Calcium } \\
\text { (mmol/mmol } \\
\text { creatinine) }\end{array}$ & $\begin{array}{l}T_{m P O} / G F R \\
(m m o l / L G F)^{\star}\end{array}$ & $\begin{array}{l}B M D \\
\left(\mathrm{gHA} / \mathrm{cm}^{2}\right)\end{array}$ & $\begin{array}{l}B M D \\
\text { (SD score) }\end{array}$ \\
\hline $\begin{array}{r}1 \\
2 \\
3 \\
4 \\
5 \\
6 \\
7 \\
8 \\
9 \\
10 \\
11 \\
12 \\
13\end{array}$ & $\begin{array}{l}5 \cdot 0 \\
4 \cdot 9 \\
4 \cdot 8 \\
4 \cdot 9 \\
4 \cdot 8 \\
5 \cdot 2 \\
4 \cdot 6 \\
4 \cdot 7 \\
4 \cdot 7 \\
4 \cdot 5 \\
4 \cdot 9 \\
4 \cdot 6 \\
4 \cdot 7\end{array}$ & $\begin{array}{l}1.45 \\
1.58 \\
1.61 \\
1.61 \\
1.61 \\
1.48 \\
1.51 \\
1.51 \\
1.51 \\
1.29 \\
1.38 \\
1.38 \\
1.28\end{array}$ & $\begin{array}{l}530 \\
430 \\
323 \\
430 \\
321 \\
381 \\
306 \\
343 \\
320 \\
320 \\
270 \\
657 \\
520\end{array}$ & $\begin{array}{r}11 \cdot 3 \\
5 \cdot 7 \\
16 \cdot 1 \\
18 \cdot 1 \\
17 \cdot 6 \\
15 \cdot 2 \\
41 \cdot 8 \\
26 \cdot 1 \\
10 \cdot 8 \\
22 \cdot 6 \\
18 \cdot 0 \\
39 \cdot 9 \\
34 \cdot 5\end{array}$ & $\begin{array}{l}199 \\
204 \\
204 \\
156 \\
204 \\
156 \\
170 \\
211 \\
213 \\
129 \\
151 \\
175 \\
185\end{array}$ & $\begin{array}{l}5 \cdot 4 \\
2 \cdot 6 \\
0.69 \\
0.56 \\
0.6 \\
5 \cdot 1 \\
0.5 \\
0.72 \\
9 \cdot 8 \\
0.4 \\
0 \cdot 4 \\
0.2 \\
0.3\end{array}$ & $\begin{array}{l}1.227 \\
1.227 \\
1.614 \\
1.647 \\
1.582 \\
1.388 \\
1.550 \\
1.873 \\
1.292 \\
1.614 \\
1.292 \\
1.453 \\
1.345\end{array}$ & $\begin{array}{l}0.38 \\
0.41 \\
0.38 \\
0.48 \\
0.56 \\
0.57 \\
0.68 \\
0.45 \\
0.58 \\
0.79 \\
0.89 \\
0.70 \\
0.76\end{array}$ & $\begin{array}{r}-2.80 \\
-1.81 \\
-2.41 \\
-0.24 \\
1.45 \\
1.66 \\
0 \\
-2.80 \\
-0.58 \\
-1.31 \\
-1.00 \\
-1.49 \\
-0.11\end{array}$ \\
\hline $\begin{array}{r}\text { Normal } \\
\text { range }\end{array}$ & $3 \cdot 8-5 \cdot 2$ & $1 \cdot 1-2 \cdot 2$ & $250-750$ & $10-35$ & $50-150$ & $0.02-0.69$ & $1 \cdot 15-2 \cdot 44$ & & \\
\hline
\end{tabular}

${ }^{\star} \mathrm{TmPO} / \mathrm{GFR}=$ tubular maximum rate of phosphate reabsorption in relation to glomerular filtration rate (LGF $=$ litre of glomerular filtrate).

BMD measurements with this equipment have a reproducibility of $0.3 \%$ in vitro and of $1 \%$ in vivo in adults. ${ }^{11} 12$ The entrance radiation dose received by the child during the examination is less than $5 \mathrm{mRem}$. Results of BMD measurements were expressed as $\mathrm{g}$ hydroxyapatite $/ \mathrm{cm}^{2}$ (gHA $/ \mathrm{cm}^{2}$ ). SD scores of BMD for chronological age were calculated using the reference values established with the same apparatus in children by Glastre et al. ${ }^{13}$ Blood and urine were analysed for calcium, phosphorus, and magnesium concentrations and blood also for alkaline phosphatase activity by standard automated chemical procedures. Intact parathyroid hormone and $1,25(\mathrm{OH})_{2}$ vitamin $\mathrm{D}_{3}$ concentrations were determined by commercial radioimmunoassay procedures (Nichols Institute, San Juan Capistrano, CA, USA). The study was approved by the ethical committee of the hospital. Statistical analysis included the Student's $t$ test and linear regression analysis.

\section{Results}

As shown in table 2, serum concentrations of calcium, phosphorus and magnesium and alkaline phosphatase activity were normal in all

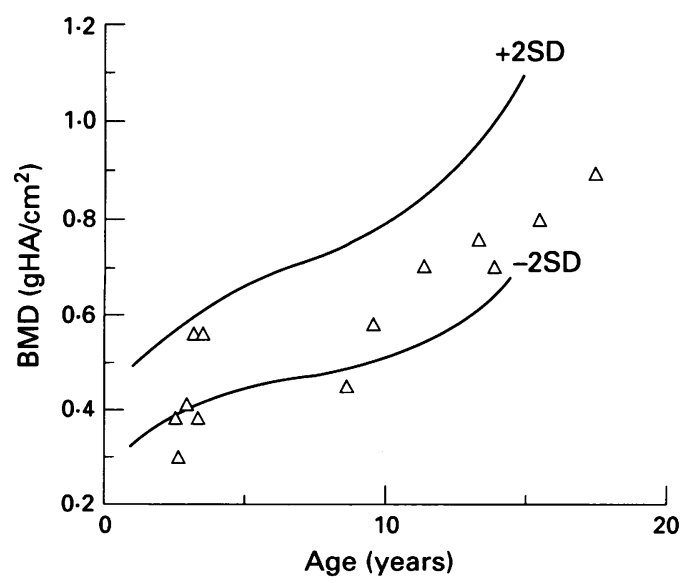

Lumbar spine $B M D$, expressed as $g H A / \mathrm{cm}^{2}$, in relation to the age of the patients. children. While $1,25(\mathrm{OH})_{2}$ vitamin $\mathrm{D}_{3}$ was normal in all patients, slightly raised parathyroid hormone concentrations were seen in two children (patients 7 and 12). An increased urinary excretion of calcium was found in five children. The excretion of the other minerals was normal in all children.

As shown in the figure, lumbar spine BMD of the patients increased with age as in normal children. Mean (SD) BMD of the patients, expressed as SD score for age, was -0.88 $(1 \cdot 44)$. Three children had a lumbar spine BMD lower than 2 SD for age (table 2), and hypercalciuria was present in two of these children. For the total group, no significant correlation could be found between the BMD SD score and the biochemical parameters. The degree of osteopenia, as reflected by the BMD $\mathrm{SD}$ score, was not related to the age of the patient, the duration of the chemotherapy, the time lapse between completion of treatment, and the time of the study. The two patients with previous irradiation as part of their treatment had a lumbar spine BMD within normal limits.

\section{Discussion}

Although monitoring of the renal tubular function in ifosfamide treated children has been proposed to predict and possibly prevent severe bone disease, few studies exist on the bone mineralisation of ifosfamide treated children or adults. Radiological signs of rickets have been reported in five out of 44 children treated with ifosfamide for a Wilms' tumour and in two out of 11 children who had received ifosfamide for a soft tissue sarcoma. ${ }^{34}$ Standard skeletal radiographs cannot detect bone loss as long as the bone mineral content has not decreased by 30 to $50 \%$.

We evaluated the bone mineralisation by dual $x$ ray absorptiometry, which is both more sensitive and more accurate than standard radiology. The lumbar spine was chosen as the site of measurement because of its high content of trabecular bone, which is more sensitive to metabolic changes than cortical bone of the extremities. By this technique, an abnormally 
low BMD was found in 3/13 patients several months after completion of chemotherapy. None of these osteopenic children had received vertebral or cranial irradiation, which may be a risk factor for bone demineralisation in leukaemia. ${ }^{14}$ One of these three osteopenic children had received prednisolone and methotrexate, both of which have been considered to cause bone demineralisation in children with leukaemia. ${ }^{15}$

Renal bicarbonate, calcium, and phosphate wastage and abnormalities in the vitamin $D$ metabolism are held responsible for the metabolic bone disease associated with severe proximal tubular dysfunction. ${ }^{16}$ These abnormalities were mostly present in the reported children with hypophosphataemic rickets induced by ifosfamide. In our study, two of the three children with osteopenia presented with a significant hypercalciuria, but none had an increased phosphate loss in the urine. Two arguments against hypercalciuria playing a major part in the mechanism of deficient bone mineralisation after ifosfamide treatment are: (1) the absence of any relationship between the degree of calciuria and bone mineralisation and (2) the persistence of hypercalciuria in children who had developed clinical rickets after ifosfamide and are cured of this disease. ${ }^{17} 18$

In accordance with most previous reports, no important abnormalities of the calcium regulating hormones were found. ${ }^{3}$ Undetectable concentrations of $1,25(\mathrm{OH})_{2}$ vitamin $\mathrm{D}_{3}$ have been observed in some patients treated with ifosfamide for a Wilms' tumour. In these patients, however, the interpretation of the results may be confounded by the possible role of other components of the treatment such as nephrectomy and irradiation of the remaining kidney. Further studies, including baseline measurements of $\mathrm{BMD}$ and bone mineral metabolism before chemotherapy as well as follow up measurements during and after stopping chemotherapy, are needed to understand the mechanism of osteopenia in some of the ifosfamide treated children.
We wish to thank Dr C Sevens and Dr J Smitz for providing the facilities for the laboratory examinations and Mrs A Schouppe for preparing the manuscript.

1 De Kraker J, Voute P. Ifosfamide, mesna and vincristine in pediatric oncology. A phase II study. Cancer Treat Rev 1983; 10: 165-6.

2 Smeitink J, Verreussel $M$, Schröder C, Lippens $R$. Nephrotoxicity associated with ifosfamide. Eur 7 Pediat 1988; 148: $164-6$.

3 Skinner R, Pearson ADJ, Price L, Coulthard MG, Craft AW. Nephrotoxicity after ifosfamide. Arch Dis Child 1990; 65: 732-8.

4 Burk CD, Restaino I, Kaplan BS, Meadows AT. Ifosfamideinduced renal tubular dysfunction and rickets in childre with Wilms' tumor. F Pediatr 1990; 117: 331-5.

5 Heney D, Wheeldon J, Rushworth P, Chapman C, Lewis IJ, Bailey CC. Progressive renal toxicity due to ifosfamide. Arch Dis Child 1991; 66: 966-70.

6 Rossi R, Helmchen U, Schellong G. Tubular function and histological findings in ifosfamide-induced renal Fanconi syndrome - a report of two cases. Eur f Pediatr 1992; 151: syndrom.

7 De Schepper J, Hachimi-Idrissi S, Verboven M, Piepsz A Otten J. Renal function abnormalities after ifosfamide treatment in children. Acta Paediatr 1993; 82: 373-6.

8 Goulding A, Campbell DR. Dietary $\mathrm{NaCl}$ loads promote calciuria and bone loss in adult oophorectomized rats consuming a low calcium diet. $f$ Nutr 1983; 113: 1409-14.

9 Oliveri MB, Cassinelli H, Bergada C, Mautalen CA. Bone mineral density of the spine and radius shaft in children with X-linked hypophosphatemic rickets (XLH). Bone Mither 1991; 12: 91-100.

10 Brenner RJ, Spring DB, Sebastian A, et al. Incidence of radiographically evident bone disease, nephrocalcinosis and nephrolithiasis in various types of renal tubularand nephrolithiasis in various types of ren
acidosis. N Engl f Med 1982; 307: 217-22.

11 Pacifici R, Rupich R, Vered I, et al. Dual energy radiograph DER): a preliminary comparative study. Calcif Tissue In 1988; 43: 189-91.

12 Kelly TL, Slovik DM, Schoenfeld DA, Neer RM. Quantitative digital radiography versus dual photon absorptiometry of the lumbar spine $f$ Clin Endocrinol Metab 1988; 67: 839-44.

13 Glastre C, Braillon P, David L, Cochat P, Meunier PJ, Delmas PD. Measurement of bone mineral content of the lumbar spine by dual energy X-ray absorptiometry in normal children: correlations with growth parameters. f Clin Endocrinol Metab 1990; 70: 1330-3.

14 Gilsanz V, Carlson ME, Roe TF, Ortega JA. Osteoporosis after cranial irradiation for acute lymphoblastic leukemia f Pediatr 1990; 117: 238-44

15 Atkinson SA, Fraher L, Gundberg CM, Andrew M, Pai M Barr RD. Mineral homeostasis and bone mass in children treated for acute lymphoblastic leukaemia. $\mathcal{F}$ Pediatr 1989 114: 793-800.

16 Stanbury SW, Lumb GA. Metabolic studies of renal osteodystrophy. Medicine (Baltimore) 1962; 41: 1-19.

17 Van Gool S, Brock P, Vijndaele G, et al. Reversible hypophosphatemic rickets following ifosfamide treatment. Med Pediatr Oncol 1992; 20: 254-7.

18 De Schepper J, Stevens G, Verboven M, Baeta C, Otten J. Ifosfamide-induced Fanconi's syndrome with growth
If failure in a 2-year-old child. Am $\mathcal{F}$ Pediatr Hematol Onco 1991; 13: 39-41. 